\title{
Regulation of Na,K-Adenosine Triphosphatase Gene Expression by Sodium lons in Cultured Neonatal Rat Cardiocytes
}

\author{
Keiji Yamamoto, " Uichi Ikeda, * Yoshitane Seino, ${ }^{\star}$ Yoshio Tsuruya, * Asahiko Oguchi, * Koji Okada," San-e Ishikawa," \\ Toshikazu Saito," Kiyoshi Kawakami," Yukichi Hara," and Kazuyuki Shimada * \\ Departments of ${ }^{*}$ Cardiology, ${ }^{\ddagger}$ Endocrinology and Metabolism, and ${ }^{\S}$ Biology, Jichi Medical School, Minamikawachi, Tochigi 329-04, \\ Japan; and "Department of Biochemistry, Tokyo Medical and Dental University School of Medicine, Yushima, Tokyo 113, Japan
}

\begin{abstract}
$\mathrm{Na}, \mathrm{K}$-ATPase ( $\mathrm{Na}, \mathrm{K}$-pump) plays an important role in the regulation of intracellular ion composition. The purpose of this study is to determine whether $\mathrm{Na}^{+}$regulates the levels of mRNA coding for $\mathrm{Na}, \mathrm{K}$-ATPase $\alpha$ and $\beta$ subunits in cultured neonatal rat cardiocytes. We measured intracellular $\mathrm{Na}^{+}$levels $\left(\left[\mathrm{Na}^{+}\right]_{i}\right)$ in cardiocytes using a $\mathrm{Na}^{+}$-sensitive fluorescence dye (SBFI). 1 mM ouabain caused a significant increase in $\left[\mathrm{Na}^{+}\right]_{\mathbf{i}}$ in cardiocytes; from $12.8 \pm 0.3$ to $28.8 \pm 1.8 \mathrm{mM}$. Exposure of cardiocytes to $1 \mathrm{mM}$ ouabain resulted in a three- to fourfold increase in $\alpha 1, \alpha 2$, and $\alpha 3$ mRNA accumulation, and an approximate two-fold increase in $\beta 1$ mRNA accumulation. $A$ maximum elevation was reached at $60 \mathrm{~min}$ in both cases. The ouabain-induced $\alpha 1$ mRNA accumulation was still observed in the $\mathrm{Ca}^{2+}$-free culture medium. Exposure of cardiocytes to 10 $\mu \mathrm{M}$ monensin in the absence of extracellular $\mathrm{Ca}^{2+}$ also resulted in a threefold increase in $\alpha 1$ mRNA accumulation. The increased $\alpha 1 \mathrm{mRNA}$ expression by $1 \mathrm{mM}$ ouabain was associated with a fourfold increase in $\alpha 1$ subunit protein accumulation. Transfection experiments with chimeric plasmids containing 5 '-flanking sequences of $\alpha 1, \alpha 2$, and $\alpha 3$ isoform genes and a luciferase reporter gene revealed that $1 \mathrm{mM}$ ouabain caused a twofold increase in luciferase activity in each $\alpha$ system. These results suggest that $\mathrm{Na}^{+}$directly regulates $\mathrm{Na}, \mathrm{K}$-ATPase gene expression in cardiocytes. The transfection study further supports the premise that $\mathrm{Na}^{+}$-responsive elements are located within the 5 -flanking sequences of each $\alpha$ isoform gene. ( $J$. Clin. Invest. 1993. 92:1889-1895.) Key words: calcium • cardiocyte $\bullet \mathrm{Na}$, T-ATPase $\bullet$ reporter gene assay • sodium pump
\end{abstract}

\section{Introduction}

$\mathrm{Na}, \mathrm{K}-\mathrm{ATPase}$ ( Na,K-pump) maintains intracellular ion composition by transporting $\mathrm{Na}^{+}$and $\mathrm{K}^{+}$against their concentration gradients across the cell membrane and plays an important role in many fundamental cellular and physiological processes, such as the control of contractility, excitability, and cell volume regulation. The $\mathrm{Na}, \mathrm{K}-\mathrm{ATPase}$ protein comprises two subunits, a large catalytic $\alpha$ subunit $\left(M_{\mathrm{r}} 112,000 \mathrm{kD}\right)(1)$ and a smaller glycosylated $\beta$ subunit $\left(M_{\mathrm{r}} 35,000 \mathrm{kD}\right)(2)$. The $\alpha$ subunit contains an intracellular ATP binding site (3), a phos-

Address reprint requests to Dr. Uichi Ikeda, Department of Cardiology, Jichi Medical School, Minamikawachi, Tochigi 329-04, Japan.

Received for publication 25 September 1992 and in revised form 11 May 1993.

J. Clin. Invest.

(C) The American Society for Clinical Investigation, Inc. 0021-9738/93/10/1889/07 $\$ 2.00$

Volume 92, October 1993, 1889-1895 phorylation site (4), and an extracellular binding site for cardiac glycosides such as ouabain and digitalis (5). The function of the $\beta$ subunit remains unknown, but it has been suggested that the $\beta$ subunit plays a role in the integration of the $\alpha$ subunit into the membrane (6). At least three $\alpha$ subunit isoforms, $\alpha 1$, $\alpha 2$, and $\alpha 3$, have been characterized in rats $(7,8)$, chickens (9), and humans (10). Two types of $\beta$ isoforms, $\beta 1$ and $\beta 2$, have been also identified in rats through cDNA cloning (11). Recently, the existence of the $\beta 3$ isoform has been reported (12). The $\alpha$ isoform gene is expressed in a tissue- and cell-specific manner (13). For example, fetal and neonatal rat cardiocytes express mainly the $\alpha 1$ and $\alpha 3$ isoforms, while adult rat cardiocytes express mainly the $\alpha 1$ and $\alpha 2$ isoforms.

Regulation of $\mathrm{Na}, \mathrm{K}-\mathrm{ATPase}$ must have a profound influence on many aspects of cellular and organismic homeostasis. In a wide variety of in vitro tissue culture systems, the levels of $\mathrm{Na}, \mathrm{K}-\mathrm{ATPase}$ mRNA accumulation are modulated in response to specific hormones, such as thyroid (14) and mineralocorticoid hormones (15). Similarly, ionic or pharmacological interventions that increase intracellular $\mathrm{Na}^{+}$levels $\left(\left[\mathrm{Na}^{+}\right]_{i}\right)$ can subsequently induce the expression of new Na,K-ATPase molecules (16-20). This has been well characterized in spontaneously beating monolayers of cultured chick heart cells, where interventions of veratridine, low- $\mathrm{K}^{+}$media, and ouabain inhibition induced significant inductions in $\mathrm{Na}, \mathrm{K}$-ATPase activity and in functional Na,K-pump sites (19). The induction of $\mathrm{Na}, \mathrm{K}$-pump sites was correlated with an increase in $\left[\mathrm{Na}^{+}\right]_{i}$, and a complementary downregulation of $\mathrm{Na}, \mathrm{K}$-pump sites was observed when external $\mathrm{K}^{+}$was replaced or veratridine was removed. Those results suggest that $\mathrm{Na}, \mathrm{K}-\mathrm{ATPase}$ gene expression is both rapidly and directly regulated by changes in intracellular ion composition in cardiocytes, and perhaps by $\left[\mathrm{Na}^{+}\right]_{\mathrm{i}}$.

In this study, we investigated regulatory mechanisms of $\mathrm{Na}, \mathrm{K}$-ATPase gene expression in cultured neonatal rat cardiocytes by $\mathrm{Na}^{+}$. We reveal that $\mathrm{Na}^{+}$directly regulates $\mathrm{Na}, \mathrm{K}-\mathrm{ATPase}$ gene expression, and that $\mathrm{Na}^{+}$-responsive sequences are located within the 5'-flanking regions of each $\alpha$ isoform gene.

\section{Methods}

Culture of neonatal rat cardiocytes. Primary cardiocytes from 1-d-old Sprague-Dawley rats were prepared using the method of Bloch et al. (21) with minor modifications (14). After a $0.25 \%$ trypsin dissociation, cell suspensions were washed with DME supplemented with $10 \%$ FBS and centrifuged at $800 \mathrm{rpm}$ for $10 \mathrm{~min}$. Centrifuged cardiocytes were resuspended in 10\% FBS containing DME supplemented with thymidine $(0.6 \mathrm{mg} / \mathrm{ml})$, penicillin $(20 \mathrm{U} / \mathrm{ml})$, streptomycin $(20 \mu \mathrm{g} /$ $\mathrm{ml})$, and gentamicin $(20 \mu \mathrm{g} / \mathrm{ml})$, and transferred to culture dishes (Falcon Labware, Oxnard, CA) at a density of $1 \times 10^{6}$ cells $/ \mathrm{ml}$. After a 72-h incubation, the medium was changed to serum-free DME supplemented with insulin $(5 \mu \mathrm{g} / \mathrm{ml})$, transferrin $(5 \mu \mathrm{g} / \mathrm{ml})$, selenium (5 
$\mathrm{ng} / \mathrm{ml}$ ), and antibiotics. Cells were used for experiments after a 12-h incubation in serum-free DME.

Measurement of $\left[\mathrm{Na}^{+}\right]_{i}$. The cultured neonatal rat cardiocytes grown on glass coverslips in 60 -mm dishes were rinsed with physiological saline solution (PSS) ${ }^{1}$ containing $140 \mathrm{mM} \mathrm{NaCl}, 4.6 \mathrm{mM} \mathrm{KCl}, 1$ $\mathrm{mM} \mathrm{MgCl}, 2 \mathrm{mM} \mathrm{CaCl}_{2}, 10 \mathrm{mM}$ glucose, and $10 \mathrm{mM}$ Hepes, $\mathrm{pH}$ 7.4. They were then loaded with $10 \mu \mathrm{M}$ sodium-binding benzofuran isophthalate acetoxymethyl ester (SBFI/AM; Molecular Probes, Eugene, OR) for $3 \mathrm{~h}$ at $37^{\circ} \mathrm{C}(22-26)$. SBFI/AM was dissolved in PSS containing $0.02 \%$ pluronic F-127; a nonionic surfactant. After the loading period, the cells on glass coverslips were rinsed with PSS and placed in a quartz cuvette in a fluorescence spectrophotometer (model CAF-100, Japan Spectrometer, Tokyo). The dual-wavelength excitation method for the measurement of SBFI fluorescence was used. The fluorescence was monitored at $500 \mathrm{~nm}$ with excitation wavelengths of 340 and $380 \mathrm{~nm}$ in the ratio mode. $\left[\mathrm{Na}^{+}\right]_{i}$ was calibrated by equilibrating $\left[\mathrm{Na}^{+}\right]_{i}$ with the extracellular $\mathrm{Na}^{+}$concentration using $1 \times 10^{-6} \mathrm{M}$ gramicidin. The reference standard solution was made from appropriate mixtures of $\mathrm{Na}^{+}$and $\mathrm{K}^{+}$, which were adjusted to $135 \mathrm{mM}$ (total $\left.\mathrm{Na}^{+}+\mathrm{K}^{+}\right)$. The $\left[\mathrm{Na}^{+}\right]_{\mathrm{i}}$ was determined from the relationship between the ratio and the authentic $\left[\mathrm{Na}^{+}\right]_{\mathrm{i}}$ as previously described $(22,23,25)$.

Measurement of $\left[\mathrm{Ca}^{2+}\right]_{i}$. Cytosolic free $\mathrm{Ca}^{2+}$ levels $\left(\left[\mathrm{Ca}^{2+}\right]_{\mathrm{i}}\right)$ of cardiocytes were estimated from fura- 2 fluorescence as previously described (22). The cells were incubated with PSS containing $5 \mu \mathrm{M}$ fura2 acetoxymethyl ester (fura-2/AM) (Dojin Biochemicals, Kumamoto, Japan ) for $60 \mathrm{~min}$ at $37^{\circ} \mathrm{C}$. After aspiration of the fura-2/AM solution, the glass slides were rinsed and then placed in a quartz cuvette at $37^{\circ} \mathrm{C}$ in a fluorescence spectrometer. The fluorescence was monitored at 500 $\mathrm{nm}$ with excitation wavelengths of 340 and $380 \mathrm{~nm}$ in the ratio mode. From the ratio of fluorescence at 340 and $380 \mathrm{~nm}$, the $\left[\mathrm{Ca}^{2+}\right]_{i}$ was determined as described by Grynkiewicz et al. (27) using the following expression: $\left[\mathrm{Ca}^{2+}\right]_{\mathrm{i}}(\mathrm{nM})=K_{\mathrm{d}} \times\left[\left(R-R_{\min }\right) /\left(R_{\max }-R\right)\right] \times \beta$, where $R$ is the ratio of fluorescence of the sample at 340 and $380 \mathrm{~nm}$, and $R_{\max }$ and $R_{\min }$ are determined by treating the cells with $5 \times 10^{-5} \mathrm{M}$ digitonin and $1 \times 10^{-2} \mathrm{M} \mathrm{MnCl}_{2}$, respectively. The term $\beta$ is the ratio of fluorescence of fura- 2 at $380 \mathrm{~nm}$ in zero and saturating $\mathrm{Ca}^{2+} . K_{\mathrm{d}}$ is the dissociation constant of fura- 2 for $\mathrm{Ca}^{2+}$, assumed to be $224 \mathrm{nM}$ at $37^{\circ} \mathrm{C}$.

Northern blot analysis. RNA was prepared from neonatal rat cardiocytes cultured on $100 \mathrm{~mm}$ dishes by the guanidinium isothiocyanate-cesium chloride method (28). Equal amounts of total RNA (10 $\mu \mathrm{g})$ were size-fractionated by electrophoresis on denaturing $1.0 \%$ agarose/ formaldehyde gels and transferred to nylon membranes (Hybond $\mathrm{N}^{+}$, Amersham Int., Amersham, Bucks., UK). Hybridizations were performed at $65^{\circ} \mathrm{C}$ for $24 \mathrm{~h}$ with an excess of [ ${ }^{32} \mathrm{P}$ ]dCTP-labeled rat $\mathrm{Na}, \mathrm{K}-\mathrm{ATPase} \alpha$ and $\beta$ subunit isoform cDNA probes ( $\mathrm{sp}$ act $>1 \times 10^{8}$ $\mathrm{cpm} / \mu \mathrm{g}$ DNA), using a multiprimer DNA labeling kit (Amersham, Int.). The $\alpha 1 \mathrm{cDNA}$ probe consisted of a $2.2 \mathrm{~kb}$ Nco I restriction fragment (7). The $\alpha 2 \mathrm{cDNA}$ probe consisted of a $2.9 \mathrm{~kb}$ fragment restricted by Sac I (7). The $\alpha 3$ cDNA probe consisted of a $1.6 \mathrm{~kb}$ Sac I-EcoR I restriction fragment (7). The $\beta 1 \mathrm{cDNA}$ probe consisted of a $0.9 \mathrm{~kb}$ Pst I restriction fragment (29). The filters were washed twice in $0.2 \times \mathrm{SSC}$ at $65^{\circ} \mathrm{C}(1 \times \mathrm{SSC}$ contains $150 \mathrm{mM} \mathrm{NaCl}, 15 \mathrm{mM}$ sodium citrate, $\mathrm{pH}$ 7.0). Autoradiography was performed at $-70^{\circ} \mathrm{C}$ overnight and quantitated by densitometric scanning ( 2202 Ultroscan, LKB Produkter, Bromma, Sweden).

ELISA for $\alpha 1$ subunit expression. Neonatal rat cardiocytes were seeded into 96-well flat-bottomed microtiter plates in $100 \mu 1 \mathrm{DME}$ containing $10 \%$ FBS and thymidine $(0.6 \mathrm{mg} / \mathrm{ml})$. After a $72-\mathrm{h}$ incubation, the medium was changed to serum-free DME, and $1 \mathrm{mM}$ ouabain was added to the wells. Cells were incubated at $37^{\circ} \mathrm{C}$ for $6 \mathrm{~h}$ in $95 \%$ air and $5 \% \mathrm{CO}_{2}$. They were washed twice with PBS containing $137 \mathrm{mM}$ $\mathrm{NaCl}, 2.7 \mathrm{mM} \mathrm{KCl}, 1.5 \mathrm{mM} \mathrm{KH}_{2} \mathrm{PO}_{4}$, and $8.1 \mathrm{mM} \mathrm{Na}_{2} \mathrm{HPO}_{4}$ before being fixed with $1 \%$ para-formaldehyde and $0.2 \%$ Triton-X for $15 \mathrm{~min}$

1. Abbreviations used in this paper: CAT, chloramphenicol acetyltransferase; PSS, physiological saline solution; SBFI/AM, sodium-binding benzofuran isophthalate acetoxymethyl ester. at room temperature. After washing the fixed cells three times with PBS, unbound sites were blocked by adding a $2 \%$ solution of BSA diluted in DME, and incubated at $37^{\circ} \mathrm{C}$ for $1 \mathrm{~h}$. After removing the blocking solution, a total of $100 \mu$ l of polyclonal rabbit anti-canine $\alpha 1$ subunit antibody (30), which can also recognize the rat $\alpha 1$ subunit, was added and plates were incubated at $37^{\circ} \mathrm{C}$ for $1 \mathrm{~h}$. The plates were then washed three times with PBS, and $100 \mu \mathrm{l}$ of a $1 / 200$ dilution of the developing antibody (donkey anti-rabbit Ig, horseradish peroxidaselinked conjugate; Amersham Int.) in 1\% BSA-DME was added. The plates were then incubated for $1 \mathrm{~h}$ at $37^{\circ} \mathrm{C}$, and the peroxidase-linked conjugate was removed and the cardiocytes were washed four times with PBS. After $100 \mu \mathrm{l}$ of 2,2'-azino-di-(3-ethylbenzthiazoline sulfonate) substrate were added to each well, the plates were incubated at $37^{\circ} \mathrm{C}$. Appropriate controls were incubated in each assay; omitting the primary antibody and/or the developing antibody and/or the substrate. The plates were read on an ELISA reader at optical density (OD) of $410 \mathrm{~nm}$ (Dynatech Laboratories, Inc., Chantilly, VA).

Constructs. A 1.8-kb Hind III fragment of the $\alpha 1$ isoform gene from the 5 '-flanking region to just before the translation initiation site in the first exon (+261) (31), a 2.5-kb BstE II fragment of the $\alpha 2$ isoform gene from the 5'-flanking region to just before the translation initiation site in the first exon $(+60)(32)$, and a 2.6-kb Hind III-Sac II fragment of the $\alpha 3$ isoform gene from the 5'-flanking region to just before the translation initiation site in the first exon $(+139)(33)$, were prepared for the reporter gene assay. Each fragment was ligated to a Hind III-digested pSV0A $/ \mathrm{L} \Delta 5^{\prime}$ vector ( $\left.\mathrm{p} \alpha \mathrm{LF}, \mathrm{p} \alpha 2 \mathrm{LF}, \mathrm{p} \alpha 3 \mathrm{LF}\right)$. $\mathrm{pSV0A} / \mathrm{L} \Delta 5^{\prime}$ is a vector containing the luciferase gene (34). The simian virus 40 (SV 40 ) enhancer and early promoter sequences are linked to the chloramphenicol acetyltransferase (CAT) coding sequence (pSV2CAT). pSV2CAT was used as an internal control of luciferase gene expression.

Transfection experiments. Neonatal rat cardiocytes were cultured on $60-\mathrm{mm}$ culture dishes in $10 \%$ FBS and thymidine $(0.6 \mathrm{mg} / \mathrm{ml})$ containing DME for $72 \mathrm{~h} .5 \mu \mathrm{g}$ of plasmids ( $\alpha \mathrm{LF}$ ) were cotransfected with $1 \mu \mathrm{g}$ of pSV2CAT into cardiocytes by the calcium phosphate coprecipitation method (35). The medium was changed to serum-free DME, followed by the addition of $1 \mathrm{mM}$ ouabain for $6 \mathrm{~h}$. Cardiocytes were harvested and lysed, and luciferase activity was measured as described (34) using a luminometer (model 1251, LKB Instruments) and normalized with CAT activity within the same cell lysate. CAT activity was assayed as described (36). The acetylated chloramphenicol was separated by thin layer chromatography, and the radioactivity was assayed using a radioanalytic imaging system (AMBIS Systems, San Diego, CA).

Miscellaneous. Data were expressed as the mean \pm SE. Statistical analysis was performed using the Student's $t$-test. $P$ values $<0.05$ were considered to indicate a statistically significant difference. Chemicals were of the highest grade commercially available.

\section{Results}

Effect of ouabain on $\left[\mathrm{Na}^{+}\right]_{i}$. We used ouabain to increase $\left[\mathrm{Na}^{+}\right]_{i}$ in cultured neonatal rat cardiocytes. Because rat $\mathrm{Na}, \mathrm{K}-\mathrm{ATPase}$ is less sensitive to ouabain, there was no significant increase in $\left[\mathrm{Na}^{+}\right]_{\mathrm{i}}$ after the addition of $0.1 \mathrm{mM}$ ouabain (Fig. $1 B$ ), however, the addition of $1 \mathrm{mM}$ ouabain caused a gradual increase in $\left[\mathrm{Na}^{+}\right]_{i}$ with a peak elevation at $5 \mathrm{~min}$ (Fig. $1 \mathrm{~A})$. As shown in Fig. 2, $1 \mathrm{mM}$ ouabain significantly increased $\left[\mathrm{Na}^{+}\right]_{\mathrm{i}}$ in cardiocytes from $12.8 \pm 0.3$ to $28.8 \pm 1.8 \mathrm{mM}$ (mean \pm SE, $P<0.01, n=6$ ).

Effect of ouabain on $N a, K-A T P a s e ~ m R N A$ expression. We decided to use $1 \mathrm{mM}$ ouabain to increase $\left[\mathrm{Na}^{+}\right]_{\mathrm{i}}$ in rat cardiocytes. After a 12-h preincubation in serum-free DME, cells were exposed to $1 \mathrm{mM}$ ouabain for $6 \mathrm{~h}$, and Na,K-ATPase $\alpha$ and $\beta$ subunit mRNA expression was analyzed by Northern blot hybridization. Cultured neonatal rat cardiocytes expressed $\alpha 1, \alpha 2, \alpha 3$, and $\beta 1$ mRNAs (Fig. 3). Incubation of cardiocytes 


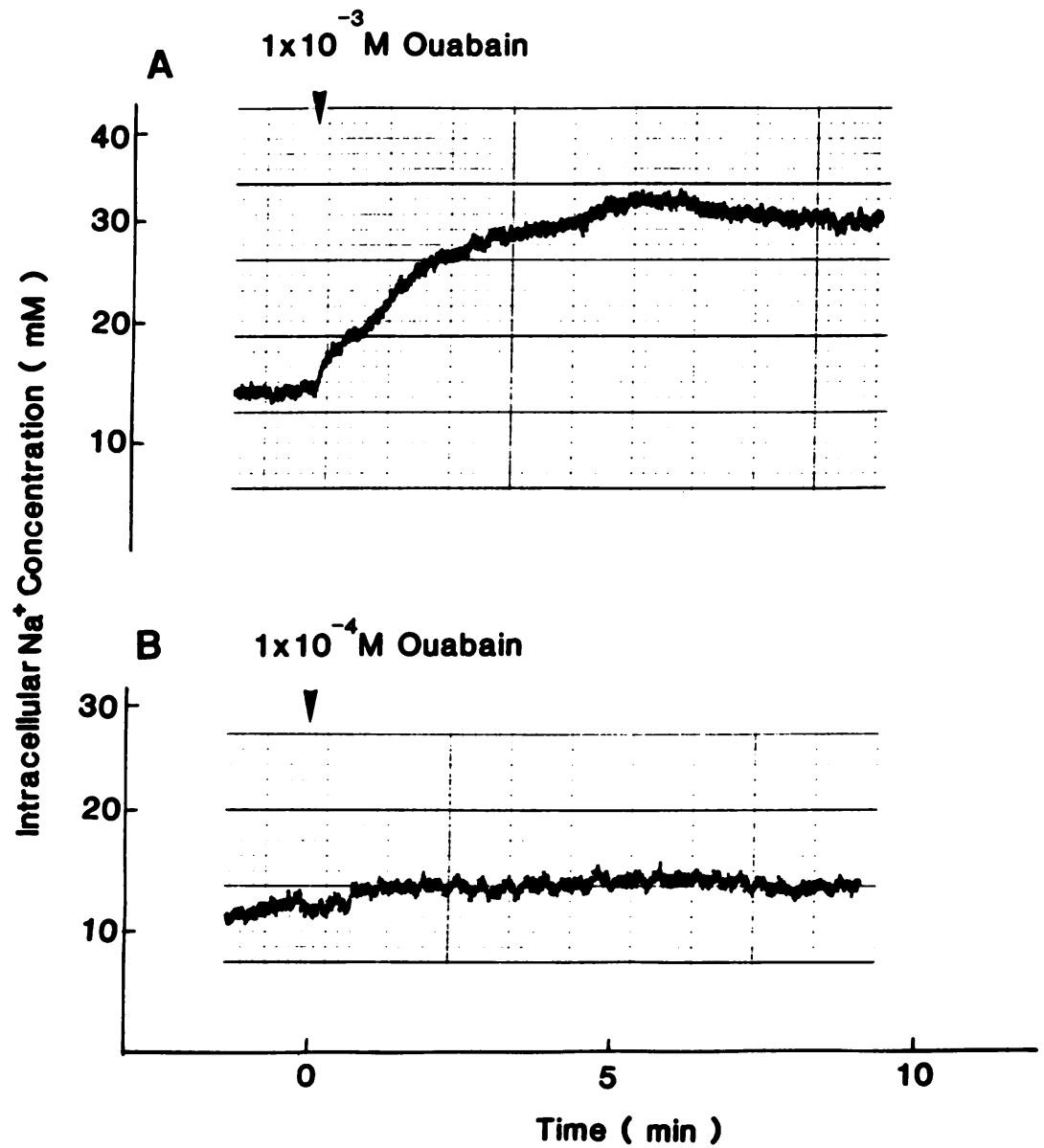

Figure 1. Time course of the ouabain-induced increase in intracellular $\mathrm{Na}^{+}$levels $\left(\left[\mathrm{Na}^{+}\right]_{\mathrm{i}}\right)$ in cardiocytes. Cultured neonatal rat cardiocytes grown on glass coverslips were incubated in DME with $10 \%$ FBS, rinsed with PSS, and were loaded with $10 \mu \mathrm{M} \mathrm{SBFI} / \mathrm{AM}$ for $3 \mathrm{~h}$ at $37^{\circ} \mathrm{C}$. After the loading period, the cells were rinsed with PSS and placed in a quartz cuvette in a fluorescence spectrophotometer. Ouabain was added to the cells after the measurement of basal $\left[\mathrm{Na}^{+}\right]_{i}$. The fluorescence was monitored at $500 \mathrm{~nm}$ with excitation wavelengths of 340 and $380 \mathrm{~nm}$ in the ratio mode. Effects of $1 \mathrm{mM}(A)$ and $0.1 \mathrm{mM}(B)$ ouabain on $\left[\mathrm{Na}^{+}\right]_{\mathrm{i}}$ were revealed. for $6 \mathrm{~h}$ in serum-free DME caused no marked changes in the $\alpha$ and $\beta$ isoform mRNA levels (data not shown), however, the addition of $1 \mathrm{mM}$ ouabain caused a rapid increase in $\alpha$ and $\beta$ isoform mRNA expression.

Fig. 4 shows the result of the quantitative analysis of Northern blot autoradiography. The stimulatory effect of $1 \mathrm{mM}$ ouabain on $\alpha 1, \alpha 2$, and $\alpha 3$ mRNA accumulation reached its maximum at $60 \mathrm{~min}$ with a three- to fourfold increase. The $\beta 1$ mRNA accumulation also reached its maximum at $60 \mathrm{~min}$ with an approximate twofold increase, in a time course similar to that of the $\alpha$ isoforms.

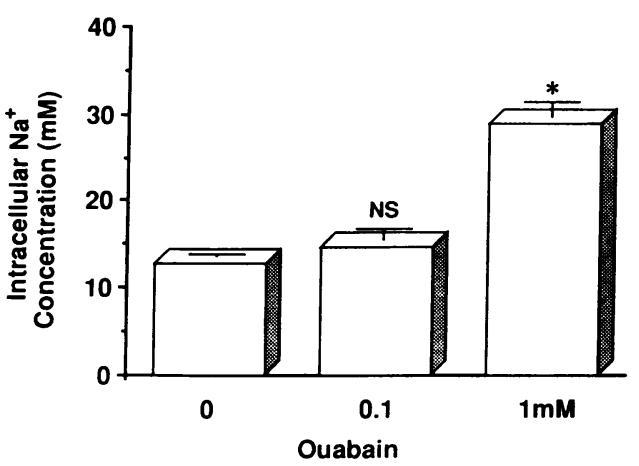

Figure 2. Effect of ouabain on $\left[\mathrm{Na}^{+}\right]_{i}$ in cultured neonatal rat cardiocytes. Values are means $\pm \mathrm{SE}$ of six samples. *Significant differences in $\left[\mathrm{Na}^{+}\right]_{\mathrm{i}}$ compared with the control value $(P<0.01)$. NS, not significant.
These results suggest that $\mathrm{Na}^{+}$upregulates $\mathrm{Na}, \mathrm{K}$-ATPase mRNA expression in cardiocytes, however, the secondary effect of increased $\left[\mathrm{Ca}^{2+}\right]_{\mathrm{i}}$ through the $\mathrm{Na}^{+} / \mathrm{Ca}^{2+}$ exchange on the mRNA expression must be also taken into account. To assess this point, we incubated rat cardiocytes in $\mathrm{Ca}^{2+}$-free DME containing $0.1 \mathrm{mM}$ EGTA. As shown in Fig. 5, even in the absence of extracellular $\mathrm{Ca}^{2+}, 1 \mathrm{mM}$ ouabain still caused a transient fourfold (4.2 \pm 0.8 ; mean $\pm \mathrm{SE}, n=3$ ) increase in $\alpha 1$ mRNA accumulation at $60 \mathrm{~min}$, suggesting that $\mathrm{Na}^{+}$, not $\mathrm{Ca}^{2+}$, regulates the mRNA expression.

To confirm that there was actually no significant increase in $\left[\mathrm{Ca}^{2+}\right]_{\mathrm{i}}$ by the addition of $1 \mathrm{mM}$ ouabain under the above experimental conditions, we measured both $\left[\mathrm{Na}^{+}\right]_{i}$ and $\left[\mathrm{Ca}^{2+}\right]_{\mathrm{i}}$ using $\mathrm{Na}^{+}$- and $\mathrm{Ca}^{2+}$-sensitive fluorescence dyes, SBFI and fura-2, respectively. The cells on glass coverslips were placed in a cuvette containing PSS or $\mathrm{Ca}^{2+}$-free PSS with 0.1 mM EGTA. On the one hand, in PSS containing $2 \mathrm{mM} \mathrm{CaCl}_{2}$, the addition of $1 \mathrm{mM}$ ouabain significantly increased both $\left[\mathrm{Na}^{+}\right]_{i}$ and $\left[\mathrm{Ca}^{2+}\right]_{i}$ in cardiocytes. On the other hand, in the absence of extracellular $\mathrm{Ca}^{2+}$, there was a significant increase in $\left[\mathrm{Na}^{+}\right]_{i}$ by $1 \mathrm{mM}$ ouabain, however, no significant increase in $\left[\mathrm{Ca}^{2+}\right]_{i}$ was observed (Table $\mathrm{I}$ ).

To investigate further whether another intervention which increases $\left[\mathrm{Na}^{+}\right]_{i}$ also stimulates $\mathrm{Na}, \mathrm{K}-\mathrm{ATPase}$ mRNA expression, we used the polyether monocarboxylic acid sodium ionophore monensin. As shown in Fig. 6, exposure of cardiocytes to $10 \mu \mathrm{M}$ monensin for a period of $60 \mathrm{~min}$ in $\mathrm{Ca}^{2+}$-free DMEM also caused an approximate threefold increase in $\alpha 1$ mRNA accumulation. 

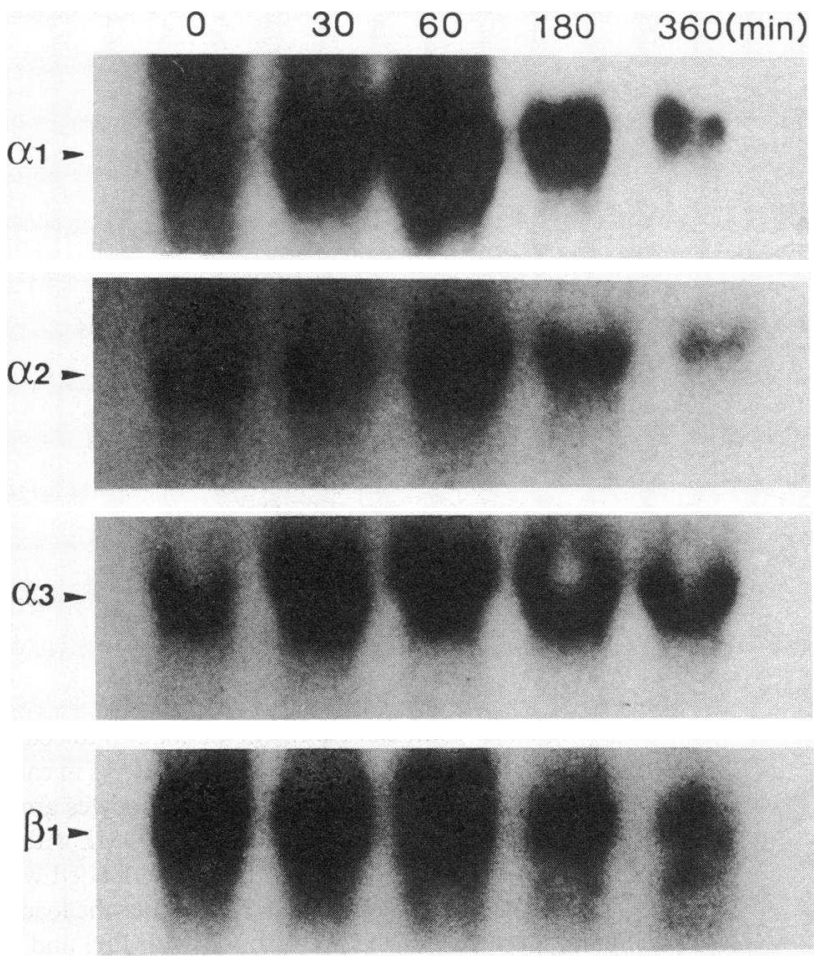

$28 \mathrm{~S}=$

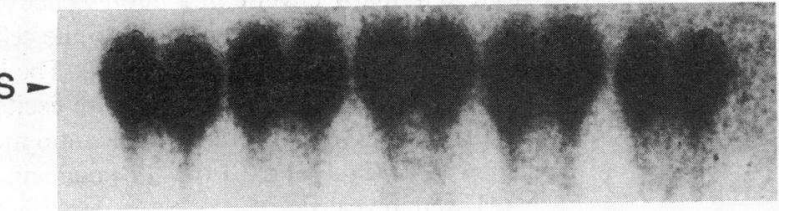

Figure 3. Induction of $\mathrm{Na}, \mathrm{K}-\mathrm{ATPase} \alpha$ and $\beta$ isoform mRNA accumulation by $1 \mathrm{mM}$ ouabain. Neonatal rat cardiocytes were prepared as described in the text and exposed to $1 \mathrm{mM}$ ouabain for the indicated periods. $10 \mu \mathrm{g}$ of total RNA was size-fractionated by $1.0 \%$ agarose/formaldehyde gel electrophoresis, transferred to nylon membranes and hybridized to excess ${ }^{32} \mathrm{P}$-labeled rat $\alpha 1, \alpha 2, \alpha 3$, and $\beta 1$ subunit cDNA probes. The $28 \mathrm{~S}$ signal was ribosome RNA, showing an equivalent appliance of total RNA onto each lane. The final wash stringency was $0.2 \times \mathrm{SSC}$ twice at $65^{\circ} \mathrm{C}$. Autoradiography was performed at $-70^{\circ} \mathrm{C}$ overnight with one intensifying screen. Data are representative of five experiments.

$\alpha 1$ subunit content. To know that the increase in $\mathrm{Na}, \mathrm{K}-\mathrm{ATPase}$ mRNA expression by ouabain was accompanied with an increase in $\mathrm{Na}, \mathrm{K}-\mathrm{ATPase}$ protein accumulation, the total amount of cellular $\alpha 1$ subunit content was determined by ELISA in permeabilized cardiocytes. In cardiocytes exposed to $1 \mathrm{mM}$ ouabain for $6 \mathrm{~h}$, the $\alpha 1$ subunit content showed a $3.7 \pm 1.0$-fold increase ( mean $\pm \mathrm{SE}, P<0.05, n=6$ ), when compared with control samples (Fig. 7). These results suggest that a $\mathrm{Na}^{+}$-mediated increase in $\alpha 1$ mRNA expression leads to an increase in $\alpha 1$ protein accumulation.

Reporter gene assay. To study whether $\mathrm{Na}^{+}$responsive sequences are located within the 5'-flanking regions of each $\alpha$ isoform, we performed a luciferase reporter gene assay. After cotransfection of $\mathrm{p} \alpha \mathrm{LF}$ and pSV2CAT into cultured neonatal rat cardiocytes, the culture medium was changed to serum-free DME, followed with the addition of $1 \mathrm{mM}$ ouabain for $6 \mathrm{~h}$. Luciferase activity was normalized by CAT activity in the same cell lysate. $1 \mathrm{mM}$ ouabain caused an approximate twofold in-

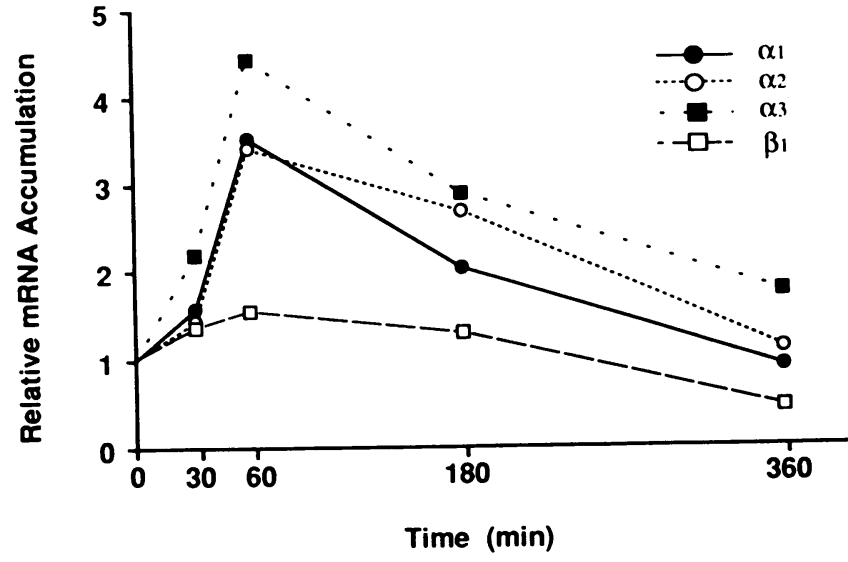

Figure 4. The time course of induction of Na,K-ATPase $\alpha$ and $\beta$ isoform mRNA accumulation. The $\alpha 1(\bullet), \alpha 2(\circ), \alpha 3(\bullet)$, and $\beta 1$ (口) mRNA levels of cardiocytes exposed to $1 \mathrm{mM}$ ouabain for the indicated periods were determined by Northern blot analysis and quantitated by densitometric scanning. The relative increase was related to the mRNA levels of zero time samples. Each point is the mean $\pm \mathrm{SE}$ of three to five separate experiments.

duction of luciferase activity in the $\alpha 1, \alpha 2$, and $\alpha 3$ isoform systems (Fig. 8), suggesting the existence of $\mathrm{Na}^{+}$-responsive sequence(s) in each $\alpha$ isoform gene.

\section{Discussion}

The results of the present study show that $\mathrm{Na}^{+}$directly regulates $\mathrm{Na}, \mathrm{K}$-ATPase $\alpha$ and $\beta$ isoform gene expression in cardiocytes. In this study, the primary culture of neonatal rat cardiac myocytes routinely yielded preparations in which $>95 \%$ of the cells were cardiocytes, as judged by their interaction with a monoclonal anti-myosin antibody (14); thus, it is unlikely that the minor degree of fibroblast contamination which existed could account for the $\mathrm{Na}^{+}$response.

$\mathrm{Na}, \mathrm{K}-\mathrm{ATPase}$ is a receptor for cardiac glycosides, such as ouabain and digitalis (5), and possesses species-associated selectivity. For example, $\mathrm{Na}, \mathrm{K}$-ATPase $\alpha 1$ isoform of rat tissue is consistently less sensitive to ouabain $\left(K_{\mathrm{i}}\right.$ of $\left.7 \times 10^{-5} \mathrm{M}\right)$ than that of the shrew, guinea pig, or rhesus monkey $(37,38)$. This is attributed to the changed amino acids present at the $\mathrm{H} 1-\mathrm{H} 2$ hinge and hence the heterogeneity of the $\alpha 1$ isoform (39). In the $\left[\mathrm{Na}^{+}\right]_{i}$ measurement experiment in rat cardiocytes with the

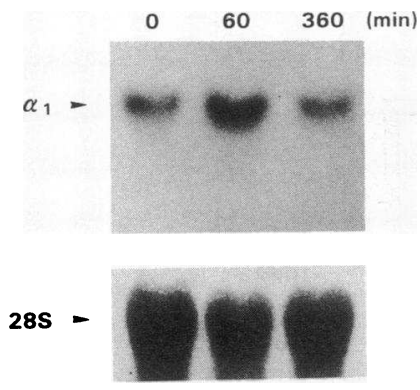

Figure 5. The $\alpha 1$ mRNA expression by $1 \mathrm{mM}$ ouabain in the $\mathrm{Ca}^{2+}$-free medium. Cardiocytes were incubated in $\mathrm{Ca}^{2+}$-free DME containing 0.1 mM EGTA and were exposed to $1 \mathrm{mM}$ ouabain for the indicated periods. $10 \mu \mathrm{g}$ of total RNA was size-fractionated by $1.0 \%$ agarose / formaldehyde gel electrophoresis, transferred to nylon membranes, and hy-

bridized to an excess of ${ }^{32} \mathrm{P}$-labeled rat $\alpha 1$ subunit cDNA probe. Data are representative of three experiments. 
Table I. Effect of Extracellular $\mathrm{Ca}^{2+}\left(\left[\mathrm{Ca}^{2+}\right]_{o}\right)$ on $1 \mathrm{mM}$ Ouabain-induced Increment in $\left[\mathrm{Na}^{+}\right]_{i}$ and $\left[\mathrm{Ca}^{2+}\right]_{i}$ in Cultured Rat Cardiocytes

\begin{tabular}{|c|c|c|c|c|}
\hline & \multicolumn{2}{|c|}{$\left[\mathrm{Na}^{+}\right]_{\mathrm{i}}$} & \multicolumn{2}{|c|}{$\left[\mathrm{Ca}^{2+}\right]_{\mathrm{i}}$} \\
\hline & Basal & Peak & Basal & Peak \\
\hline & \multicolumn{2}{|c|}{$m M$} & \multicolumn{2}{|c|}{$n M$} \\
\hline $2 \mathrm{mM}\left[\mathrm{Ca}^{2+}\right]_{\mathrm{o}}$ & $11.33 \pm 0.44$ & $31.33 \pm 2.62^{*}$ & $85.50 \pm 5.14$ & $131.19 \pm 11.91^{\ddagger}$ \\
\hline $0 \mathrm{mM}\left[\mathrm{Ca}^{2+}\right]_{0}$ with $0.1 \mathrm{mM}$ EGTA & $13.80 \pm 0.60$ & $49.83 \pm 4.04^{*}$ & $25.80 \pm 1.83$ & $24.00 \pm 2.10$ \\
\hline
\end{tabular}

Values are means \pm SE, $n=4$ experiments. ${ }^{*} P<0.001,{ }^{\ddagger} P<0.02$ vs. basal values.

$\mathrm{Na}^{+}$-sensitive fluorescence dye, we revealed that $0.1 \mathrm{mM}$ ouabain showed no significant increase in $\left[\mathrm{Na}^{+}\right]_{i}$, but $1 \mathrm{mM}$ ouabain caused a significant increase in $\left[\mathrm{Na}^{+}\right]_{i}$.

In a wide variety of in vivo and in vitro systems, $\mathrm{Na}, \mathrm{K}$-ATPase expression is stimulated by interventions which increase $\left[\mathrm{Na}^{+}\right]_{i}$. It has been reported previously that the exposure of HeLa cells (18), chick heart cells (19), and ARL 15 cells (16) to media with low $\mathrm{K}^{+}$brings about an increase in the amount of $\mathrm{Na}, \mathrm{K}$-ATPase molecules on the plasma membrane. Hsu and Guidotti (38) reported that the expression of the $\alpha 2$ isoform mRNA was increased in rat skeletal muscles on the low potassium diet owing to an increase in $\left[\mathrm{Na}^{+}\right]_{\mathrm{i}}$. Pressley et al. (16) reported similar results with ARL 15 cells after their exposure to low extracellular $\mathrm{K}^{+}$concentrations $\left(\left[\mathrm{K}^{+}\right]_{0}\right)$ and high $\left[\mathrm{Na}^{+}\right]_{\mathrm{i}}$; in which case there were threefold increases in the $\alpha 1 \mathrm{mRNA}$ and 1.7 -fold increase in the $\beta$ mRNA. Boardman et al. (40) suggested that stimulation of $\mathrm{Na}, \mathrm{K}-\mathrm{ATPase}$ abundance by $\mathrm{K}^{+}$-depletion or ouabain treatment is signaled by $\left[\mathrm{Na}^{+}\right]_{i}$ because upregulation did not occur in the $\mathrm{Na}^{+}$-free medium. Culter et al. (41) used monensin to raise $\left[\mathrm{Na}^{+}\right]_{\mathrm{i}}$ and found the same upregulation of $\mathrm{Na}, \mathrm{K}-\mathrm{ATPase} \alpha$ subunit gene in HeLa cells as that obtained with growth in low- $\mathrm{K}^{+}$medium, and concluded that a rise in $\left[\mathrm{Na}^{+}\right]_{i}$ was responsible for the upregulation.

$\left[\mathrm{Na}^{+}\right]_{i}$ may be associated with many cellular actions such as action potential, ion exchanges, and maintenance of intracellular $\mathrm{pH}$, controlled by $\mathrm{Na}, \mathrm{K}-\mathrm{ATPase}, \mathrm{Na}^{+} / \mathrm{H}^{+}$, and $\mathrm{Na}^{+} /$ $\mathrm{Ca}^{2+}$ exchanges. It must also be noted that the experimental intervention that increases $\left[\mathrm{Na}^{+}\right]_{\mathrm{i}}$ can also induce changes in intracellular osmolarity, $\mathrm{pH}, \mathrm{Ca}^{2+}$, or a combination of the above. Our study suggest that $\mathrm{Na}^{+}$directly upregulates the expression of Na,K-ATPase mRNA, but the secondary effect of $\mathrm{pH}$ or $\mathrm{Ca}^{2+}$ on Na,K-ATPase gene expression must be considered. We observed that the upregulation of $\mathrm{Na}, \mathrm{K}-\mathrm{ATPase}$ gene

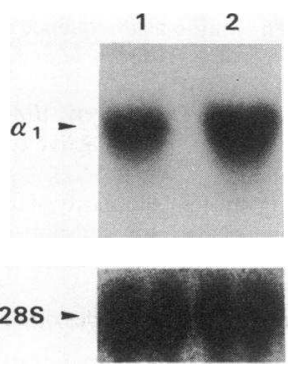

Figure 6. Induction of $\alpha 1 \mathrm{mRNA}$ accumulation by monensin in the absence of extracellular $\mathrm{Ca}^{2+}$. Cultured neonatal rat cardiocytes in $\mathrm{Ca}^{2+}$-free DME containing $0.1 \mathrm{mM}$ EGTA were exposed (lane 2) or not exposed (lane 1 ) to $10 \mu \mathrm{M}$ monensin for $60 \mathrm{~min} .10 \mu \mathrm{g}$ of total RNA was sizefractionated by $1.0 \%$ agarose/formaldehyde gel electrophoresis, transferred to nylon membranes, and hybridized to an excess of ${ }^{32} \mathrm{P}$-labeled rat $\alpha 1$ subunit cDNA probe. Data are representative of three experiments. expression by ouabain was not affected in the presence of 1 $\mathrm{mM}$ amiloride, an inhibitor of the $\mathrm{Na}^{+} / \mathrm{H}^{+}$exchange (data not shown), suggesting no involvement of the $\mathrm{Na}^{+} / \mathrm{H}^{+}$exchange in the ouabain-induced $\mathrm{Na}, \mathrm{K}$-ATPase mRNA expression.

Another conceivable effect of the treatments that result in the upregulation of $\mathrm{Na}, \mathrm{K}-\mathrm{ATPase} \mathrm{mRNA}$ expression is a rise in $\left[\mathrm{Ca}^{2+}\right]_{i}$ through a secondary stimulation of the $\mathrm{Na}^{+} / \mathrm{Ca}^{2+}$ exchange. Recently, Rayson (42) reported that elevation of [ $\left.\mathrm{Ca}^{2+}\right]_{\mathrm{i}}$ stimulated both $\alpha 1$ and $\beta 1 \mathrm{mRNA}$ levels in suspensions of outer medullary tubular segments. However, Wolitzky and Fambrough (43) observed that the attempt to raise $\left[\mathrm{Ca}^{2+}\right]_{i}$ selectively by the exposure of the cells to the calcium ion ionophore A23187 did not result in any change in the amount of $\mathrm{Na}, \mathrm{K}-\mathrm{ATPase}$, while veratridine significantly stimulated biosynthesis of $\mathrm{Na}, \mathrm{K}-\mathrm{ATPase}$, concluding that $\mathrm{Na}^{+}$rather than $\mathrm{Ca}^{2+}$ is important in the stimulus for the upregulation of $\mathrm{Na}, \mathrm{K}-\mathrm{ATPase}$. We investigated the expression of $\alpha 1 \mathrm{mRNA}$ in $\mathrm{Ca}^{2+}$-free DME containing $0.1 \mathrm{mM}$ EGTA. In the absence of extracellular $\mathrm{Ca}^{2+}, 1 \mathrm{mM}$ ouabain significantly increased $\left[\mathrm{Na}^{+}\right]_{i}$, but not $\left[\mathrm{Ca}^{2+}\right]_{i}$, and still induced a transient fourfold increase in $\alpha 1 \mathrm{mRNA}$ expression. Furthermore, monensin also stimulated $\alpha 1 \mathrm{mRNA}$ expression in the absence of extracellular $\mathrm{Ca}^{2+}$. These results support the premise that the induction of $\mathrm{Na}, \mathrm{K}$-ATPase mRNA in cardiocytes by ouabain occurs solely in response to the elevation of $\left[\mathrm{Na}^{+}\right]_{i}$.

In the present study, we observed that increased $\left[\mathrm{Na}^{+}\right]_{\mathrm{i}}$ induced by $1 \mathrm{mM}$ ouabain caused a transient increase in $\mathrm{Na}, \mathrm{K}-\mathrm{ATPase}$ mRNA accumulation with a peak elevation at $60 \mathrm{~min}$. The reason for the fall in the mRNA accumulation after $60 \mathrm{~min}$ is unresolved. In the $\mathrm{Ca}^{2+}$-free medium, $1 \mathrm{mM}$ ouabain still caused a transient increase in $\alpha 1 \mathrm{mRNA}$ accumulation, suggesting that contracture of the cells by calcium overload is not a cause. Bowen and McDonough (44) also observed a transient increase in $\alpha$ and $\beta$ subunit mRNA accumulation in

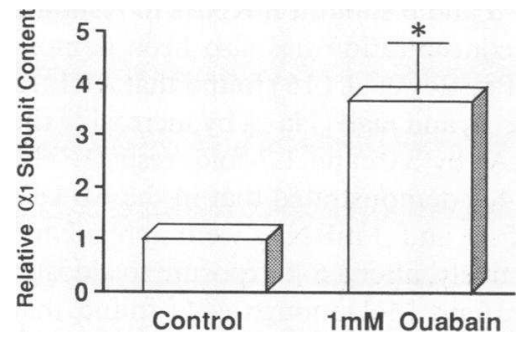

Figure 7. The $\alpha 1$ protein accumulation analyzed by ELISA. Cultured neonatal rat cardiocytes were pretreated in serum-free DME for $12 \mathrm{~h}$, and $1 \mathrm{mM}$ ouabain was added to the medium for $6 \mathrm{~h}$. ELISA (OD at $410 \mathrm{~nm}$ ) was performed as described

in the text. Data are expressed as a relative increase in OD in ouabain-treated cells to nontreated cells (control). Data are mean \pm SE of six samples; ${ }^{*} P<0.05$ compared with the control. 


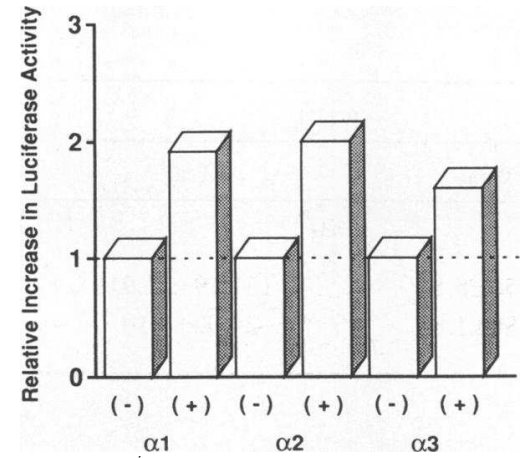

Figure 8. Relative increase in luciferase activity enhanced by 1 mM ouabain. Two types of chimeric plasmids, $p \alpha L F(p \alpha 1 L F$ $\mathrm{p} \alpha 2 \mathrm{LF}, \mathrm{p} \alpha 3 \mathrm{LF}$ ) containing each $\alpha$ isoform 5 '-flanking region in the 5 ' end of the luciferase coding sequence, and pSV2CAT containing the simian virus 40 (SV40) enhancer and

early promoter sequences in the $5^{\prime}$ end of CAT, were used. They were cotransfected into cultured neonatal rat cardiocytes by the calcium phosphate coprecipitation method. After transfection, the medium was changed to serum-free DME, followed by the addition of $1 \mathrm{mM}$ ouabain for $6 \mathrm{~h}$. Luciferase activity was measured using a luminometer and normalized with CAT activity in the same cell lysate. The acetylated chloramphenicol was separated by thin-layer chromatography. The radioactivity was assayed using a radioanalytic imaging system. Data are expressed as a relative increase in luciferase activity in ouabain-treated cells $(+)$ to nontreated cells $(-)$.

cultured canine kidney cells, which peaked at 60 min after initiation of low $\mathrm{K}^{+}$incubation, followed by a decrease over the next several hours. Taormino and Fambrough (17) reported that veratridine caused a transient twofold increase in the number of Na,K-pump molecules on the surface of cultured chicken myotubes, which was paralleled by a transient threefold increase in the amount of $\beta$ mRNA. Wolitzky and Fambrough (43) also observed a transient increase in the biosynthesis of $\mathrm{Na}, \mathrm{K}-\mathrm{ATPase}$ molecules by veratridine in chick myogenic cultures, with a peak synthesis at $12 \mathrm{~h}$. Rayson (45) reported a transient increase in the rate of $\mathrm{Na}, \mathrm{K}-\mathrm{ATPase}$ synthesis occurred after $12 \mathrm{~h}$ of ouabain treatment in cultured kidney cells. We also observed that the exposure of rat cardiocytes to low $\left[\mathrm{K}^{+}\right]_{0}(0.8 \mathrm{mM})$ caused a transient threefold increase in $\alpha 1$ mRNA expression, with a peak elevation at 60 $\min (46)$.

At least two types of $\beta$ isoforms, $\beta 1$ and $\beta 2$, have been characterized in rats by cDNA cloning (11), and recently the existence of the $\beta 3$ isoform has been reported (12). The function of the $\beta$ subunit remains unknown, but it has been suggested that the $\beta$ subunit plays a role in the integration of the $\alpha$ subunits into the membrane (6). $1 \mathrm{mM}$ ouabain caused only a twofold increase in the $\beta 1 \mathrm{mRNA}$ level, with a maximum elevation at $60 \mathrm{~min}$, while each $\alpha \mathrm{mRNA}$ level increased three- to fourfold, in a time course similar to that of the $\beta 1$ mRNA. Discordant regulation of $\alpha$ and $\beta$ subunit mRNAs in response to perturbations in ion concentration has also been demonstrated in other systems. Pressley et al. (16) found that ARL 15 cells responded to low $\left[\mathrm{K}^{+}\right]_{0}$ and high $\left[\mathrm{Na}^{+}\right]_{\mathrm{i}}$ by increasing the levels of $\alpha 1$ and $\beta$ mRNAs by 3.0- and 1.7-fold, respectively. Verrey and co-workers (47) demonstrated that in the A6 kidney cell line the levels of $\alpha 1$ and $\beta$ mRNAs were upregulated two- and fourfold, respectively, after a 6-h exposure to aldosterone. In contrast, Bowen and McDonough (44) found that exposure of MDCK cells to low $\left[\mathrm{K}^{+}\right]_{0}$ elicited a coordinate threefold induction in $\alpha 1$ and $\beta$ mRNAs. Taken together, these results suggest that the net increases in the accumulation of $\mathrm{Na}, \mathrm{K}-\mathrm{ATPase}$ in response to perturbations in $\left[\mathrm{Na}^{+}\right]_{\mathrm{i}}$ are me- diated, generally, by increases in $\alpha$ and $\beta$ mRNAs. However, the onset, relative levels, and timing in the regulation of $\alpha$ and $\beta$ mRNA levels vary in different cell types and in response to different stimuli.

Various approaches have been employed to quantitate $\mathrm{Na}, \mathrm{K}-\mathrm{ATPase}$ protein content. Although $\left[{ }^{3} \mathrm{H}\right]$ ouabain binding is often used, this approach is difficult in rat tissue because of the relative low ouabain binding affinity of the rat $\alpha 1$ subunit (37). ELISA analysis allows for an accurate measurement of changes in total $\alpha 1$ subunit protein, and have revealed that a $\mathrm{Na}^{+}$-mediated increase in $\alpha 1 \mathrm{mRNA}$ accumulation was accompanied by an increase in $\alpha 1$ protein accumulation.

In this study, $\mathrm{Na}^{+}$caused a rapid increase in $\mathrm{Na}, \mathrm{K}-\mathrm{ATPase}$ $\alpha$ and $\beta$ subunit gene expression in cardiocytes. Mineralocorticoid (15) and thyroid hormone (14) also stimulate $\alpha 1$ mRNA expression in cardiocytes, however, over a more gradual time course with a peak elevation at 6 and $48 \mathrm{~h}$, respectively. The rapid change in the mRNA level by ouabain suggests that transcription is directly regulated, since it is unlikely that a regulatory protein could be synthesized to activate transcription within such a short period. There exists strong evidence that the ion- and hormone-mediated regulation of $\mathrm{Na}, \mathrm{K}-\mathrm{ATPase}$ are achieved through different mechanisms (48). To further investigate whether $\mathrm{Na}^{+}$-responsive elements are located within the 5'-flanking regions of each $\alpha$ isoform, we performed a reporter gene assay and observed that $1 \mathrm{mM}$ ouabain caused a twofold increase in luciferase activity in each $\alpha$ isoform system. We therefore speculate $\mathrm{Na}^{+}$responsive sequences are located within the $5^{\prime}$-flanking regions of each $\alpha$ isoform and $\mathrm{Na}^{+}$directly stimulates $\mathrm{Na}, \mathrm{K}-\mathrm{ATPase}$ gene transcription, even though the $\mathrm{Na}^{+}$-responsive sequence location still remains unknown.

The apparent necessity of cardiocytes to express $\mathrm{Na}, \mathrm{K}$-pump sites to compensate for the high $\mathrm{Na}^{+}$load is important. In this study, we revealed that $\mathrm{Na}^{+}$directly regulates $\mathrm{Na}, \mathrm{K}-\mathrm{ATPase}$ gene expression in cardiocytes and $\mathrm{Na}^{+}$-responsive sequences might be located within the 5 '-flanking regions of each $\alpha$ isoform.

\section{Acknowledgments}

The authors thank Russell M. Medford, M.D., Ph.D. (Emory University School of Medicine) for his helpful discussion. We also thank Toshiko Kanbe for her technical assistance.

This study was supported by the Ministry of Education, Culture and Science, the Takeda Medical Research Foundation, and the Asahi Life Welfare Foundation (Japan).

\section{References}

1. Shull, G. E., A. Schwarts, and J. B. Lingrel. 1985. Amino-acid sequence of the catalytic subunit of the $\left(\mathrm{Na}^{+}+\mathrm{K}^{+}\right)$ATPase deduced from a complementary DNA. Nature (Lond.). 316:691-695.

2. Shull, G. E., L. K. Lane, and J. B. Lingrel. 1986. Amino-acid sequence of the $\beta$-subunit of the ( $\mathrm{Na}^{+}+\mathrm{K}^{+}$)ATPase deduced from a cDNA. Nature (Lond.). 321:429-431.

3. Farley, R. A., C. M. Tran, C. T. Carill,, D. Hawke, and J. E. Shively. 1984 The amino acid sequence of a fluorescein-labeled peptide from the active site (Na,K)-ATPase. J. Biol. Chem. 259:9532-9535.

4. Bastide, F., G. Meissner, S. Fleischer, and R. L. Post. 1973. Similarity of the active site of phosphorylation of the adenosine triphosphatase for transport of sodium and potassium ions in kidney to that for transport of calcium ions in the sarcoplasmic reticulum of muscle. J. Biol. Chem. 248:8385-8391.

5. Langer, G. A. 1981. Mechanism of action of the cardiac glycosides on the heart. Biochem. Pharmacol. 30:3261-3264. 
6. Hiatt, A., A. A. McDonough, and I. S. Edelman. 1984. Assembly of the $\left(\mathrm{Na}^{+}+\mathrm{K}^{+}\right)$-adenosine triphosphatase. J. Biol. Chem. 259:2629-2635.

7. Shull, G. E., J. Greeb, and J. B. Lingrel. 1986. Molecular cloning of three distinct forms of the $\mathrm{Na}^{+}, \mathrm{K}^{+}$-ATPase $\alpha$-subunit from rat brain. Biochemistry. 25:8125-8132.

8. Herrera, V. L. M., J. R. Emanuel, N. Ruiz-Opazo, R. Levenson, and B. Nadal-Ginard. 1987. Three differentially expressed Na,K-ATPase $\alpha$ subunit isoforms: Structural and functional implications. J. Cell Biol. 105:1855-1865.

9. Takeyasu, K., K. J. Renaud, J. Taormino, B. A. Wolitzky, A. Barnstein, M. M. Tamkun, and D. M. Fambrough. 1989. Differential subunit and isoform expression involved in regulation of sodium pump in skeletal muscle. Curr. Top. Membr. Transp. 34:143-165.

10. Shull, M. M., and J. B. Lingrel. 1987. Multiple genes encode the human $\mathrm{Na}^{+}, \mathrm{K}^{+}$-ATPase catalytic subunit. Proc. Natl. Acad. Sci. USA. 84:4039-4043.

11. Martin-Vasallo, P., W. Dackowski, J. R. Emanuel, and R. Levenson. 1989. Identification of a putative isoform of the Na,K-ATPase $\beta$ subunit. J. Biol. Chem. 264:4613-4618.

12. Good, P. J., K. Richter, and I. B. Dawid. 1990. A nervous system-specific isotype of the $\beta$ subunit of $\mathrm{Na}^{+}, \mathrm{K}^{+}$-ATPase expressed during early development of Xenopus laevis. Proc. Natl. Acad. Sci. USA. 87:9088-9092.

13. Orlowski, J., and J. B. Lingrel. 1988. Tissue-specific and developmental regulation of rat $\mathrm{Na}, \mathrm{K}-\mathrm{ATPase}$ catalytic $\alpha$ isoform and $\beta$ subunit mRNAs. $J$. Biol. Chem. 263:10436-10442.

14. Kamitani, T., U. Ikeda, S. Muto, K. Kawakami, K. Nagano, Y. Tsuruya A. Oguchi, K. Yamamoto, Y. Hara, R. M. Medford, et al. 1992. Regulation of $\mathrm{Na}, \mathrm{K}$-ATPase gene expression by thyroid hormone in rat cardiocytes. Circ. Res. 71:1457-1464.

15. Ikeda, U., R. Hyman, T. W. Smith, and R. M. Medford. 1991. Aldosterone-mediated regulation of $\mathrm{Na}, \mathrm{K}-\mathrm{ATP}$ ase gene expression in adult and neonatal rat cardiocytes. J. Biol. Chem. 266:12058-12066.

16. Pressley, T. A., F. Ismail-Beigi, G. G. Gick, and I. S. Edelman. 1988. Increased abundance of $\mathrm{Na}^{+}-\mathrm{K}^{+}$-ATPase mRNAs in response to low external $\mathrm{K}^{+}$. Am. J. Physiol. 255:C252-C260.

17. Taormino, J. P., and D. M. Fambrough. 1990. Pre-translational regulation of the $\left(\mathrm{Na}^{+}+\mathrm{K}^{+}\right)$-ATPase in response to demand for ion transport in cultured chicken skeletal muscle. J. Biol. Chem. 265:4116-4123.

18. Pollack, L. R., E. H. Tate, and J. S. Cook. 1981. $\mathrm{Na}^{+}, \mathrm{K}^{+}$-ATPase in HeLa cells after prolonged growth in low $\mathrm{K}^{+}$or ouabain. J. Cell. Physiol. 106:85-97.

19. Kim, D., J. D. Marsh, W. H. Barry, and T. W. Smith. 1984. Effects of growth in low potassium medium or ouabain on membrane $\mathrm{Na}, \mathrm{K}-\mathrm{ATPase}$, cation transport and contractility in cultured chick heart cells. Circ. Res. 55:39-48.

20. Brodie, C., and S. R. Sampson. 1985. Effects of chronic ouabain treatment on $\left[{ }^{3} \mathrm{H}\right]$ ouabain binding sites and electrogenic component of membrane potential in cultured rat myotubes. Brain Res. 347:121-123.

21. Bloch, K. D., J. G. Seidman, J. D. Naftilan, J. T. Fallon, and C. E. Seidman. 1986. Neonatal atria and ventricles secrete atrial natriuretic factor via tissue-specific secretory pathways. Cell. 47:695-702.

22. Okada, K., S. Ishikawa, and T. Saito. 1991. Mechanisms of vasopressininduced increase in intracellular $\mathrm{Na}^{+}$in vascular smooth muscle cells. Am. J. Physiol. 261:F1007-F1012.

23. Ishikawa, S., K. Okada, and T. Saito. 1990. Prompt inhibition of arginine vasopressin-induced cellular adenosine 3',5'-monophosphate production by extracellular sodium depletion in rat renal inner medullary collecting duct cells in culture. Endocrinology. 127:560-566.

24. Minta, A., and R. Y. Tsien. 1989. Fluorescent indicators for cytosolic sodium. J. Biol. Chem. 264:19449-19457.

25. Okada, K., S. Ishikawa, and T. Saito. 1990. Effect of vasopressin on $\mathrm{Na}^{+}$ kinetics in cultured rat vascular smooth muscle cells. Biochem. Biophys. Res. Commun. 173:224-230.

26. Borzak, S., M. Reers, J. Arruda, V. K. Sharma, S. Sheu, T. W. Smith and J. D. Marsh. 1992. $\mathrm{Na}^{+}$efflux mechanisms in ventricular myocytes: measurement of $\left[\mathrm{Na}^{+}\right]_{i}$ with $\mathrm{Na}^{+}$-binding benzofuran. Am. J. Physiol. 263:H866-H874.

27. Grynkiewicz, G., M. Poenie, and R. Y. Tsien. 1985. A new generation of $\mathrm{Ca}^{2+}$ indicators with greatly improved fluorescent properties. J. Biol. Chem. 260:3440-3450.
28. Chirgwin, J. M., A. E. Przybyla, R. J. MacDonald, and W. J. Rutter. 1979. Isolation of biologically active ribonucleic acid from sources enriched in ribonuclease. Biochemistry. 18:5294-5299.

29. Young, R. M., G. E. Shull, and J. B. Lingrel. 1987. Multiple mRNAs from rat kidney and brain encode a single $\mathrm{Na}^{+}, \mathrm{K}^{+}$-ATPase $\beta$ subunit protein. J. Biol. Chem. 262:4905-4910.

30. Masuzawa, T., T. Ohta, K. Kawakami, and F. Sato. 1985. Immunocytochemical localization of $\mathrm{Na}^{+}, \mathrm{K}^{+}$-ATPase in the canine choroid plexus. Brain. 108:625-646

31. Yagawa, Y., K. Kawakami, and K. Nagano. 1990. Cloning and analysis of the $5^{\prime}$-flanking region of rat $\mathrm{Na}^{+} / \mathrm{K}^{+}$-ATPase $\alpha$ l subunit gene. Biochim. Biophys. Acta. 1049:286-292.

32. Kawakami, K., Y. Yagawa, and K. Nagano. 1990. Regulation of $\mathrm{Na}^{+}, \mathrm{K}^{+}$-ATPases: I. Cloning and analysis of the 5'-flanking region of the rat NKAA2 gene encoding the $\alpha 2$ subunit. Gene. 91:267-270.

33. Pathak, B. G., D. G. Pugh, and J. B. Lingrel. 1990. Characterization of the 5 '-flanking region of the human and rat Na,K-ATPase $\alpha 3$ gene. Genomics. 8:641-647.

34. DeWet, J. R., K. V. Wood, M. DeLuca, D. R. Helinski, and S. Subramani. 1987. Fire-fly luciferase gene: Structure and expression in mammalian cells. Mol. Cell. Biol. 7:725-737.

35. Chen, C., and H. Okayama. 1987. High-efficiency transformation of mammalian cells by plasmid DNA. Mol. Cell. Biol. 7:2745-2752.

36. Gorman, C. M., L. F. Moffat, and B. H. Howard. 1982. Recombinant genomes which express chloramphenicol acetyltransferase in mammalian cells. Mol. Cell. Biol. 2:1044-1051.

37. Iizuka, H., and H. Atai. 1987. Ouabain susceptibility of heart muscle of the house musk shrew, an insectivore: a comparison with the rat, guinea pig and rhesus monkey. J. Pharmacobio-Dyn. 10:353-355.

38. Hsu, Y., and G. Guidotti. 1991. Effect of hypokalemia on the properties and expression of the Na,K-ATPase of rat skeletal muscle. J. Biol. Chem. 266:427-433.

39. Price, E. M., and J. B. Lingrel. 1988. Structure-function relationships in the Na,K-ATPase $\alpha$ subunit: site-directed mutagenesis of glutamine-111 to arginine and asparagine-122 to aspartic acid generates a ouabain-resistant enzyme. Biochemistry. 27:8400-8408.

40. Boardman, L. J., M. Huett, J. F. Lamb, J. P. Newton, and J. M. Polson. 1974. Evidence for the genetic control of the sodium pump density in HeLa cells. J. Physiol. (Lond.). 241:771-794.

41. Culter, P., C. Cramb, and J. F. Lamb. 1988. Quantitative analysis of sodium pump-specific mRNA from human endothelial (HeLa) and canine kidney (MDCK) cell culture. In The $\mathrm{Na}^{+}, \mathrm{K}^{+}$-ATPase Pump. J. C. Skou, J. G. Norby, A. B. Maunsbach, and M. Esmann, editors. Alan R. Liss, Inc., New York. 59-64.

42. Rayson, B. M. 1991. $\left[\mathrm{Ca}^{2+}\right]_{\mathrm{i}}$ regulates transcription rate of the $\mathrm{Na}, \mathrm{K}-\mathrm{ATP}$ ase $\alpha 1$ subunit. J. Biol. Chem. 266:21335-21338.

43. Wolitzky, B. A., and D. M. Fambrough. 1986. Regulation of the $\left(\mathrm{Na}^{+}\right.$ $+\mathrm{K}^{+}$)-ATPase in cultured chick skeletal muscle: modulation of expression by the demand for ion transport. J. Biol. Chem. 261:9990-9999.

44. Bowen, J. W., and A. McDonoguh. 1987. Pretranslational regulation of Na-K-ATPase in cultured canine kidney cells by low $\mathrm{K}^{+}$. Am. J. Physiol. 252:C179-C189.

45. Rayson, B. M. 1989. Rates of synthesis and degradation of $\mathrm{Na}^{+}-\mathrm{K}^{+}-\mathrm{ATP}-$ ase during chronic oubain treatment. Am. J. Physiol. 256:C75-C80.

46. Ikeda, U., M. J. O'Neill, T. W. Smith, and R. M. Medford. 1988. A molecular comparison of thyroid hormone and ion-mediated regulation of $\mathrm{Na}, \mathrm{K}-\mathrm{ATPase}$ gene expression in in vitro rat cardiocytes. Circulation. 78:II-242 (Abstr.).

47. Verrey, F., E. Schaerer, P. Zoerkler, M. P. Paccolat, K. Geering, J. P. Kraehenbuhl, and B. C. Rossier. 1987. Regulation by aldosterone of $\mathrm{Na}^{+}, \mathrm{K}^{+}$-ATPase mRNAs, protein synthesis, and sodium transport in cultured kidney cells. J. Cell. Biol. 104:1231-1237.

48. Rossier, B. C., K. Geering, and J. P. Kraehenbuhl. 1987. Regulation of the sodium pump: how and why?. Trends Biochem. Sci. 12:483-487. 